\title{
Social Entrepreneurialism and Social Media in Post-developmental state Taiwan
}

\author{
You-tien Hsing
}

In this chapter I use social entrepreneurialism as an analytical tool to understand the changing state-society relationship in Taiwan since the 1990s. ${ }^{1}$ I adopt the usual definition of entrepreneurship, which includes the capacity to identify and exploit opportunities and resources, endure risks, innovate, and create new values. In the expanding literature on social entrepreneurialism, especially from the field of business management, much of the debate has focused on what social entrepreneurialism is and should be, framed by the role of commercial exchange (e.g., should social entrepreneurs worry about profitability?), the goals of entrepreneurial activities (e.g., can social entrepreneurs serve nonsocial purposes?), and the hybrid model exemplified by the Grameen Bank in Bangladesh and other microcredit agencies that are profit oriented but using profits to achieve social goals.

While these works are useful in establishing links between ideals and policy formulations, it is equally important to contextualize and politicize the formation and transformation of social entrepreneurialism and to examine its connections with other types of entrepreneurialism. By doing so, I hope to understand to what extent social entrepreneurialism is convergent with and divergent from the logic of the state and the market.

While this chapter focuses on Taiwan in the era of the post-martial law, postdevelopmental state, I will also discuss the role of the connection between Taiwan and mainland China in the development of social entrepreneurialism. 


\section{TAIWAN IN THE ERA OF THE POST-MARTIAL LAW, POSTDEVELOPMENTAL STATE}

The developmental state is usually defined by the interventionist state's policies of industrial restructuring and export upgrading as well as investment in public education to produce an upgradable labor force. In Taiwan, the success of microelectronics and Hsinchu Science Park has been well recognized as the showcase achievement of the developmental state. The developmental state is also frequently typified by an authoritarian regime. The combination of single-party domination, legitimized by the threat of Chinese communist invasion from across the Taiwan Strait, and successful land reform that effectively removed the landed elite in rural areas in the 1950 s helped to keep workers and farmers relatively quiet in the regime of accumulation, characterized by high investment, low wages, and large price scissors, from the 1950 s through the 1980 os.

These four pillars of the developmental state, namely, state-guided and exportoriented industrialization, public education, rural land reform, and authoritarianism, have been substantially transformed since the early 1990s. In the 1990s, Taiwan's political system evolved from single-party authoritarianism under the Nationalist Party (KMT) to multiparty democracy, accompanied by the rise of social activism after the lifting of martial law in 1987. Also in the 1990s, while Taiwan's microelectronics companies continued to occupy an important niche in the world market, they faced new challenges and began to shift standardized manufacturing to mainland China. Public education first took a neoclassical turn in the early 1990s, using a supply-side rationale to increase the number of universities, hence lowering the threshold to university entrance. It then made a neoliberal turn in the early 200os, adopting quantitative measurements in performance evaluation in higher education and encouraging private investment in education at all levels. Traditional agriculture went through crises as a result of urban and industrial expansion, insufficient state protection, and the World Trade Organization. Some rural areas survived by shifting to high-value-added agriculture and leisure industries, while others deteriorated further. These transformations in the era of the postdevelopmental state intertwined with one another, generating dilemmas, contentions, and new dynamics among the state, society, and the market.

The transformation of microelectronics showcased the changing state-society relationship in Taiwan in the new era. Since the 1990s, microelectronics, along with many other export-oriented manufacturing sectors, began to move to mainland China. As the issue of Taiwan's growing connection with mainland China continued to dominate political debates in Taiwan, the Taiwanese government dealt with the challenge of industrial hollowing out by diversifying the high-tech sector and by expanding existing science parks and building new ones. New science parks were built in agricultural areas, such as Tainan in southern Taiwan, 
Yilan on the northeast coast, and Houli in central Taiwan. Hsinchu Science Park triumphalism has lent much symbolic capital to the new parks. Some of the science parks were central government initiatives, but many more were local politicians' pet projects. This spatial strategy of decentralizing science parks reflects the changing political landscape in Taiwan in the postauthoritarian era. The two rival parties, the Democratic Progressive Party (DPP) and the Nationalist Party (Kuomintang, KMT), competed with each other to consolidate their political support by allocating public projects in their client counties and cities.

To ensure profitability in projects that involved both public and private interests, plans of science parks were usually accompanied by real estate development projects. A science park that could accommodate both industrial and residential/ commercial development required the conversion of large areas of farmland.

In 2004, a plan to build a science park and develop the surrounding areas for real estate projects was prepared by the county government of Miaoli in central Taiwan. Given its location to the south of Hsin-chu, the planned park tried to borrow the fame of Hsinchu Science Park and was called Chu-nan (South of Hsinchu) Science Park. One of the subsidiaries of Foxconn, the iconic Taiwanese firm that manufactures 80 percent of the world's iBooks and iPads and Nokia and Motorola cell phones, was a prospective tenant of the planned park. According to the plan, the farmland of a village called Dapu, among others, was earmarked for land use conversion. The proposal did not meet much resistance in the beginning, as the county governor promised Dapu villagers high compensation rates for their farmland, and the villagers' homes were to be left intact so there was no need for relocation.

By 2008 , the Foxconn subsidiary requested a much larger area of land in the park for its future expansion. To accommodate the request, the Miaoli county government decided to expropriate more farmland from Dapu village; further, the new expansion plan would involve demolition of villagers' homes and hence villagers' relocation. Even more controversial, the compensation rates turned out to be much lower than the "premium rates" that the governor had originally promised. Villagers responded by organizing rallies and protests in front of the Executive Yuan and the Control Yuan, the national-level government branches in Taipei. On June 9, 2010, before any agreement was reached between farmers and the county government, and as the rice crop was almost ready for harvest, the county government unexpectedly sent more than twenty excavators into the rice fields in the wee hours of the morning. The excavators were accompanied by two hundred police officers and an ambulance. In the name of preparing the land for construction, the fleet of excavators began a rampage of destruction of the rice fields of Dapu village.

As the extractors destroyed richly laden crops, and as anguished old farmers and women with young children pleaded with the operators to stop the monster 
machines and were held back brutally by the police, a local resident videotaped the entire incident. A citizen journalist, pen-named Great Tyrannosaurus, edited the footage and posted the video on a popular Web platform of citizen journalism called PeoPo (or People's Post). The video, entitled When the Excavators Came to the Rice Fields, immediately went viral. It subsequently activated a massive mobilization of local farmers, social activists, media workers, students, public intellectuals, professionals, and artists across Taiwan to protest against the government's brutality in land appropriation. The Dapu incident triggered one of the most important social movements in Taiwan's recent memory. At the end, the chief of the Executive Yuan apologized to Dapu villagers, and President Ma Ying-jeou of the KMT vetoed the expansion plan.

The societal challenge to the expansion of microelectronics and science parks in Taiwan also came from other sources. Pollution created by the microelectronics firms in Hsinchu Science Park had been an important target of environmental activists and community groups since the mid-199os. Yet because the park was embedded in the state bureaucracy and the sewer and drainage systems were centralized in the science park, the administration of the science park, rather than individual polluting firms, became the target of the environmental protesters. Also, complaints were lodged mainly by residents in the neighborhoods adjacent to the park, where many middle-class employees of the science park lived. The split interests and loyalties between employees of Hsinchu Science Park and nonemployees in the same community made it difficult for the movement to strengthen its solidarity and attract a greater following.

The movement against high-tech pollution started to gather momentum in the 20oos. The political strategy of building patronage by dispensing high-profiled science park projects in greenfield sites began to provoke waves of activism against high-tech pollution. As areas affected by high-tech pollution expanded from the neighboring middle-class communities to farmers' croplands, the environmentalists' voice became louder.

Meanwhile, the significance of the legendary Industrial Technology Research Institute (ITRI) and the Electronics Research and Service Organization (ERSO), the star state actors and the base of high-tech research and development in Taiwan in the 1980s and 1990s, has been diminishing. Since the late 1990s, most high-tech firms have developed worldwide technology sourcing and strategic partnerships; many have established in-house research centers as the war over intellectual property rights in the microelectronics industry has escalated. ${ }^{2}$ Taiwan's anti-high-tech pollution activists linked up with activist groups in the United States, especially those based in the Silicon Valley. They learned from their Silicon Valley counterparts to target individual polluting firms, like Acer and Foxconn, that were located outside of park jurisdiction and were not under the protective umbrella of the science park administration. ${ }^{3}$ 
Targeting these well-known firms individually was also a way to get media attention and impose greater pressure on the firms. Similar protests against industrial pollution were found in other sectors, including another foundational industry of the developmental state: the petrochemical industry. ${ }^{4}$ In April 2011, a persistent and well-networked campaign by farmers, students, public intellectuals, professionals, and environmentalist groups successfully forced the government to halt a plan to build a major petrochemical complex in a wetland area in Zhanghua County on Taiwan's southwestern coast, making another headline and benchmarking the progress of Taiwan's environmental movement.

Yet not all social mobilizations in Taiwan have brought victorious results. What is important about mobilization is the way people are mobilized. The mobilization that I briefly sketched above, among many other similar cases, marked a profound transformation of Taiwan's state-society relationship in the era of the postdevelopmental state. What had once been the showcase of the developmental state, the microelectronics and petrochemical industries, was now as much a political liability as an economic driver. Growth-based legitimacy projects were subjected to societal scrutiny on environmental and distributional fronts and became the platform of social contestations.

Another related issue in the post-developmental state era is a changing perception of development that has challenged the idea and ideal of development defined by economic growth. Along with expanding social activism over distributional issues with regard to labor, the environment, land rights, women, education, and aborigines' rights, the politics of recognition and representation are also on the rise. The developmental state that once prioritized quantitative growth is now challenged by a new socioculture that asks questions about development for whom, and for what.

The question of "development for whom" has driven distributional and representational social movements since the 1990s; the question of "development for what" has formed the basis of religious and spiritual movements. Both types of movements are tightly connected with social actions, social values, and social entrepreneurialism.

Before I go into case studies to elaborate on these two types of social entrepreneurialism, I will first sketch briefly the transformation of Taiwan's social movements from political entrepreneurialism in the 1990s, characterized by its dependence on political parties, to the social entrepreneurialism in the 2000 , characterized by more diverse and autonomous forms of social mobilization.

\section{FROM POLITICAL TO SOCIAL ENTREPRENEURIALISM}

In 2000, the opposition party that grew out of Taiwan's democracy movement, the DPP, won the presidential election. Its victory marked the shift of Taiwan's polity from single-party domination to competitive multiparty democracy. The 
DPP started out opposing the monopoly of the KMT and came to encompass a wide spectrum of political opposition, including agendas for legislature reform, labor, ethnic minority rights, aborigines' rights, and women's rights. Consolidating a very diverse array of progressive political movements in the 1990s, Chen Shui-bian of the DPP won the presidency in 2000 and stayed in power for two four-year terms.

Through the election the DPP developed a symbiotic relationship with grassroots activists turned political entrepreneurs. The grassroots organizations gave the DPP candidates political credibility and a campaign agenda; the DPP, in return, endorsed and sponsored movement leaders' election campaigns or recruited them into the government and party bureaucracy at various levels. While the DPP enjoyed both political resources and social legitimacy, social movements were made highly dependent on the DPP regime throughout the 1990s and a good part of the 200os.

But the story of political entrepreneurialism is not just one of co-opted radicalism or political opportunism. Since the 2000 , the repertoire of social contestation and mobilization started to expand from distributional politics, as in the case of labor protection and women's rights, to the politics of recognition, as in the case of the rights of aboriginals, religious groups, and gay men and lesbians. However, as the repertoire of social activisms expanded and diversified, not all of them were endorsed by the DPP establishment, which had shifted from being an opposition party to occupying the center of power.

Along with the diversification and expansion of social movements and agendas, there was another wave of cultural change in the 20oos: voicing opinions in public forums and protesting and mobilizing were normalized, and networking in real and cyber space became a way of life. The various forms of civil organizations and social movements as well as the culture of protest through new and old media created varied real and virtual spaces jointly occupied by different classes, including workers and farmers; community organizers; liberal media workers; student groups, teachers, public intellectuals, academics; white-collar workers and professionals in medicine, law, design, and engineering; spiritual and religious activists; parents, housewives, and even woman marriage migrants from Southeast Asia.

The organizational capacity of these groups varied greatly, and not all of them were "political" according to narrowly defined party and electoral politics. Some specifically labeled themselves as "apolitical." Nevertheless, all of them engaged in social networking, coordinated by active members of the networks, which expanded and overlapped with other networks. The culture of networking has always been deeply rooted in Taiwanese society. It was now much expanded and reinforced, thanks to the widely available IT infrastructure in the age of information.

These loosely or not-so-loosely organized networkers were socially engaged but were not necessarily "political" in the immediate sense. Members were highly 
aware of the public agenda and possessed a mobilizational capacity that could be readily put into action when the need arose.

Several commentators in Taiwan have pointed out that by the end of the 2000 s Taiwan's social activism was moving toward a more autonomous arena. The new generation of social activists and organizers had looser connections, if any, with either the DPP or the KMT party machines. They were politically shrewd and were highly aware of the cost of dependency on dominant political parties. They were less constrained by the state's political and policy agendas and were more internationally connected. While these activists claimed to be more community oriented than "political," their networks had a strong political implication in that they marked the emergence of a nonstate space and remained mobilizable for political aims. Activists had well-coordinated social networks that they could mobilize politically, even if not for specific political projects like election campaigns. In the instance already noted of a recent environmental protest against a plan to build a mega petrochemical complex and a new science park in central Taiwan, student groups, environmentalists, writers, and artists organized, fought, and won the battle.

Growing out of a political mobilization confined by party politics of the $1980 \mathrm{os}$ and 1990s, social movements in Taiwan have gone through important transformations and have become increasingly conscious of the need to preserve their own autonomy in the volatile environment of party politics. I call this phenomenon social entrepreneurialism in the sense that resourceful and creative social activists have been able to mobilize for social causes, creating social meanings and defining social values.

\section{CITIZEN JOURNALISM AND PEOPLE'S POST}

Social entrepreneurialism in the new millennium has a lot to do with informational technology. With this in mind, I have identified a citizen journalist network called People's Post ("PeoPo" for short), established in Taiwan in 2007, to examine Taiwan's social entrepreneurialism and its relationship with social media.

In Taiwan in the 1990 s and 2000s, as the relatively new democracy encountered the global trend of deregulation, the number of media outlets increased dramatically. Shifting from highly controlled and censored, state-dominant public media, by 2011 Taiwan had five terrestrial TV networks, nine twenty-four-hour news channels, nineteen national evening newscasts, 120 cable channels, and an over 85 percent cable TV penetration rate. There are four thousand magazines, 2,500 newspapers, and two hundred radio stations - all for a population of 23 million. While Taiwan ranked fourth of countries in Asia for freedom of the press, it ranked last in media credibility, at only 1 percent. ${ }^{5}$ In 2007 , a survey conducted by Taiwan Normal University found that two-thirds of the citizens thought the 
media was the most important cause of Taiwan's social disorder. ${ }^{6}$ Under intense competition for advertising, news programs grew increasingly sensational, and political parties and politicians bought up slots in news programs in the form of product placement. As commodified news programs in the commercial media generated widespread public distrust, in 2007 Public Television in Taiwana public broadcaster much like the BBC in the United Kingdom-launched the multimedia citizen journalism website People's Post or PeoPo, based on the opensource operating system Linux.7 The English pronunciation of PeoPo is close to that for the word "tips" in Taiwanese slang.

PeoPo is different from personal blogs in the sense that the reports are more public affairs oriented, focusing more on local community events; and the stories are firsthand reporting instead of commentaries at second hand on news reports. ${ }^{8}$ Compared to one of the best-known citizen journalism projects in East Asia, OhMyNews of South Korea, Taiwan's PeoPo emphasizes grassroots autonomy and does not interfere with or moderate the materials sent by citizen journalists, as long as those journalists are registered with the public TV station by their real name to prevent frauds and hoaxes. If someone objects to a report, the objection is forwarded to the contributor, who is invited to reconsider and amend it if he or she wants to. The TV station reserves the right to remove material, but it has not found any case that made the removal necessary. Also, whereas contributors to OhMyNews in South Korea are known to have close affiliations with traditionally strong political groups like teachers' associations and labor unions, most PeoPo citizen journalists are independent news producers. Of the 5,313 citizen journalists in PeoPo as of September 2011, 45 percent were male and 55 percent female. They tended to be young (70 percent between ages twenty and forty), and well educated (9o percent with college or higher degrees, as compared to the 36 percent of Taiwan's population over age fifteen with college or higher degrees). Compared to the $\mathrm{BBC}$, which "welcomes viewers' contribution of photos and videos" but nevertheless treats these contributors as "sources", and other social news organizations like ProPublica of the United States, which is mainly an outlet for elite grant-sponsored professional journalists, citizen journalists of PeoPo primarily come from a nonmedia background and have great control over their reporting. Between April 2007 and March 2012, citizen journalists contributed seventy thousand reports, and the number of visitors grew from less than two hundred thousand per month in 2007 to a million by $2012 .{ }^{9}$

When Typhoon Morakot hit southern Taiwan in August 2009, killing more than seven hundred people and causing widespread devastation, it was a local citizen journalist who uploaded the first video report from the disaster zone that alerted the political center of Taipei in the north, which was basking in the sun that day. With its widespread and persistent team of video reporters, the PeoPo project shamed the government into getting much-needed aid to the stricken areas, and 
Taiwan's president Ma Ying-jeou came under fire for his slow response to the disaster and his belated appeal for international help.

As PeoPo was getting more participating citizen journalists and visitors, the Public Television channel began to integrate PeoPo's output into its news programs. There was a daily five-minute program on the best stories filed that day. On weekends the main news bulletins carried at least four PeoPo reports. And it was not just public television that used citizen journalists' reports. Commercial TV stations also covered stories that were first broken by citizen journalists and that became too widely circulated for the commercial media to ignore. PeoPo citizen journalists did not just report from the grassroots. They began to set the social agenda. By covering what the mainstream media shied away from, citizen journalists gained credibility that most of the commercial media had long lost. And as citizen journalists established their social credibility, their political legitimacy was also strengthened. During the 2008 presidential election, PeoPo initiated a program that selected twelve citizen-produced videos from three hundred submissions, in which each citizen raised a thirty-second question for the presidential candidates. These twelve participants were invited to appear at the live broadcast of presidential debates, and each had the chance to ask the candidates a follow-up question face to face.

The connection between Taiwan's social entrepreneurialism and PeoPo is about intensification and expansion of social networks, and the capability of creating richly interwoven and mutually reinforcing relationships among various types of networks: social and virtual networks, personal and institutional networks, existing and expanded networks. In a society that has had a long and rich tradition of networking among extended families, friends, businesses, neighbors, and colleagues, the newly opened political environment, high computer literacy rates, and the availability of information technologies have provided the foundation for existing personal and business networks to flourish with effective coordination and organization.

A good example of the accumulative and expansive nature of networking that integrates social and virtual networks is the frequent and regular meetings of citizen journalists. As a way to maintain the quality of reporting, with a strong focus on visual stories, the public television station organized an extensive training program for member citizen journalists. In addition to producing fifty online training videos and courses, the station has run more than four hundred face-to-face workshops, organized citizen journalist gatherings, field visits, and symposiums, given citizen journalist awards, and held summer camps in different regions in Taiwan. Also, Taiwan's nonprofit, non-degree-granting community colleges in Taiwan, which have proliferated since the early 2000 s and now total seventy-five throughout the island, offer journalism courses for aspiring citizen journalists. In the training programs, newcomers and experienced citizen journalists meet, and 
community workers and social activists share their experiences and interact directly with like-minded citizens. The meetings, workshops, and courses are informative and fun. They are for professional training in camerawork, interview skills, writing, and editing, as well as for socializing and network expansion.

Networking also extends from information production and circulation to action. The networks between citizen journalists and social activists constitute another important dimension of social entrepreneurialism.

Generally speaking, about 80 percent of the agenda covered by the sixty-thousand-plus citizen journalist reports between 2007 and 2011 were directly related to public affairs. Within that 80 percent, 23 percent concerned social welfare, 17 percent education, 12 percent the environment, 8 percent politics and the economy, 7 percent the media, 6 percent community reform, 6 percent historic preservation, 4 percent agriculture, 15 percent daily life and leisure, and 2 percent sports and technology. ${ }^{10}$

Although citizen journalists are mostly independent producers, their concerns regarding public affairs bring them close to social movements and organizations. Social protests or mobilizational activities are rarely covered by commercial media, as the most media are entangled with political and corporate interests. Social activists consequently count on citizen journalists to spread the word and mobilize support. The connection between PeoPo and social movements has helped strengthened both. The mobilization around the Dapu incident in 2010, as presented earlier in this chapter, was triggered by a citizen journalist's video report. Active social groups in Taiwan, like the Taiwan Agriculture United Front, among others, decided to join the Dapu-triggered farmers' land rights movement after activists saw the posting. Activists provided much-needed organizational resources and mobilization skills to sustain the movement. The sustained mobilization in turn provided more materials for citizen journalists, brought them more visitors, and encouraged them to follow the movement in greater depth. ${ }^{11}$ PeoPo itself is affiliated with fifteen college news centers (which are usually affiliated with schools of journalism) and more than two hundred nongovernmental and nonprofit organizations, holding training workshops for them. These training programs have turned socially concerned citizens not only into more effective visual and auditory communicators but also into regular visitors and active participants of PeoPo. A news platform with the idea of sharing and voicing from the bottom up has become an unparalleled example of networking for the production of social meanings and values.

Another example of the synergy created across different types of networks is the linkage between interpersonal and mobilizational networks. In the movement against the plan to build a petrochemical complex in southern coastal Taiwan, the turning point happened when a mainstream news magazine, Business Weekly in Taiwan, decided to cover the story, which all other mainstream media had shied 
away from. According to Zhuang Feng-jia, one of the reasons for Business Weekly to cover the story was that a leading activist of the movement, a university professor, was a close college friend of the executive editor of the magazine. ${ }^{12}$ The latter was convinced by the college friend to do what other mainstream media intentionally neglected. The coverage was critical because it was only after reading the story in Business Weekly that President Ma decided to veto the project. What is also interesting is the cross-fertilizing between citizen journalism and liberal journalism. The report was filed by a woman journalist who had left a mainstream media outlet and had become a freelancer and a registered citizen journalist of PeoPo. She eventually won the prestigious national journalism award for her persistent reporting on the explosive environmental issue.

To sum up, the significance of PeoPo as a critical case of social entrepreneurialism in Taiwan in the era of the postdevelopmental state is as follows.

First, PeoPo has an unusual relationship with the state and market. Like citizen journalism in other parts of the world, PeoPo enjoys the social credibility that mainstream commercial media does not. What makes PeoPo particularly interesting is its relationship with the state in the era of the postdevelopmental state. From its birth, PeoPo was a part of the Taiwan Public Television Service (TPTS) and has enjoyed the privilege of not having to worry about its commercial viability. It could also tap into the infrastructure and platform of the public TV station, as one of the fruits of Taiwan's political opening. Unlike some of the North America-based public journalist platforms like NowPublic (Vancouver, established in 2005), Newsvine (Seattle, 2005), and Reddit (Medford, MA, 2005), which ran like business startups and were subsequently acquired by mainstream media and/or venture capital, PeoPo managed to maintain its autonomy from the market.

There is a price to pay for financial autonomy. The leadership of the TPTS has been a political appointment. In 2007, when PeoPo was first established at the TPTS, the general manager of the TPTS was a student leader turned senior professional journalist who was well respected in Taiwan's media circles. His vision and support helped PeoPo stay away from political entanglements during his tenure. After the general manager left the TPTS, PeoPo went through several ups and downs, during which its budgetary and personnel resources were much limited. According to the director of the PeoPo platform, PeoPo's saving grace came from its claim to be a form of "new media," the magic words at a time when traditional print media continued to decline and when, as mentioned before, conventional TV news had lost much of its credibility. Moreover, PeoPo has become so successful that it is frequently presented at various international conferences on media, democracy, or new media. Whenever Taiwan needs to show the world what democracy has done for the Taiwanese people, especially when compared to mainland China, PeoPo makes a good showcase for Taiwan and for the TPTS. Consequently, as the director of PeoPo told me, even though the new TPTS leadership does not always support 
what PeoPo does, it cannot afford to seriously trim its already humble budget (less than 1 percent of the total TPTS budget). The highly resourceful and low-paid staff at PeoPo has therefore found its small, yet relatively autonomous space within the TPTS and has kept partisan politics at bay.

Second, PeoPo goes beyond elite professionalism. It has maintained the nonelitist nature of reporting, while remaining devoted to the provision of technical training to grassroots journalists through regular workshops and joint training programs with community colleges and social activist groups. ${ }^{13}$ These training workshops have proved to be very effective in both technical training and social networking.

Many active citizen journalists are teachers who took early retirement under Taiwan's generous pension plans in the 1990s. These primary and secondary school teachers, with their broad knowledge base, communication skills, and experiences in visual presentation, were able to get a handle on news production quickly. With the support of state-sponsored pension plans, these middle-aged retirees can afford to devote their time and energy to volunteer work, including citizen journalism. This is yet another link between the state and social entrepreneurialism.

Third, PeoPo and network society reinforce one another. Supported by a welldeveloped IT infrastructure in a highly urbanized island of high population density, and embedded in a society of high computer literacy and dense social networks, PeoPo exemplifies how different types of networks can overlap, connect, and expand into more extensive networks. These multilayered networks are simultaneously interpersonal, institutional, and communicational-informational. They reinforce one another, creating new synergy in a society that turned into a multiparty democracy only twenty years ago (or eleven years ago, if we use the successful presidential campaign of the oppositional DPP as the benchmark). The extensiveness of social-informational networks and a functioning democracy seem to have created a positive feedback loop in this case.

Last but not the least, PeoPo features crucial links between its expansive and extensive communication networks and mobilizational actions. PeoPo's nonpartisan and noncommercial stance in a highly commercialized and politicized Taiwan gave it the rarest commodity of all: public trust and social credibility that turned out to be an effective tool for mobilization for the public good.

\section{THE INTERNET AND PUBLIC TRUST IN CHINA}

The public trust that PeoPo enjoyed makes an intriguing contrast with the Internet culture that James Leibold and Rongbin Han have reported on. ${ }^{14}$

Leibold used Manuel Castells's concept of "networked individualism" to elaborate on the fraudulent culture of the Internet generally. In an article entitled "Blogging Alone" he argued that "while the internet has dramatically increased people's access to information, it also threatens to undermine the accuracy and meaning 
of much of this knowledge."15 Examples of Internet rumors, misinformation, and deception abound in the China of the 2000s. In the wake of the 2003 SARS epidemic, online rumors suggested that the virus was a biological weapon invented by Taiwan and the United States to destroy China, while stores ran out of vinegar once it was suggested as the only antidote to the infection. ${ }^{16}$

One of the best-known examples of deception and forgery on China's Internet concerns a tiger. The South China tiger, Panthera tigris amoyensis, had not been seen in the wild since 1980. But in October 2007, when a farmer and amateur photographer in the northwestern Chinese province of Shaanxi claimed he had risked his life to shoot thirty-plus digital photographs of a South China tiger in the wild, the Provincial Forestry Bureau immediately threw their weight behind the authenticity of the farmer's snapshots. They rushed to hold a press conference to announce the "rediscovery" of the extinct tiger under their jurisdiction, in the hope that it would boost the fame of the place, get state recognition and funding to establish a protection zone for the tiger like the giant panda conservancy in Sichuan, and increase tourism. However, the photographs were soon questioned. Netizens doubted the pictures and claimed they were fake. Urged by the public and wildlife experts, the national Forestry Ministry formed an investigative team on October 24, but their report has remained unpublicized. By early 2008, the Shaanxi provincial government reprimanded the Forestry Bureau for violating official regulations by holding the press conference to support Zhou's "discovery" without further evidence. The Forestry Bureau subsequently issued a public letter apologizing for publicizing the photos, though it refrained from commenting about their authenticity.

What's interesting is that the embarrassing scandal did not stop others from trying their luck with the same hoax. Only one month after the farce of the "paper tiger" in Shaanxi subsided, another scandal involving a fake South China tiger was exposed. This time, the person who did the forgery was a journalist with a county TV station in Hunan Province, another poor and desperate region. The journalist announced that he had "unintentionally videotaped" a suspected South China tiger in a mountainous area of Hunan Province. Again, local officials immediately jumped to support the claims. High-level provincial and municipal officials paid an inspection tour to the site where the tiger had allegedly been videotaped. They concluded that the journalist's videotape was authentic. But just four days later, the provincial Forestry Bureau announced that the big cat in the film was in fact a Siberian tiger borrowed from a circus from another province that happened to be on a performance tour in Hunan. The journalist was subsequently blamed for making the forgery to enhance his own fame and commercial interests. ${ }^{17}$ Neither the officials who supported the forgery nor the journalist was punished.

While the case of the South China tiger forgeries was eventually cleared up, many other forgeries have remained on the Internet. One immediate consequence 
of these scandals is that information on the Internet is increasingly considered unreliable. Online anonymity protects individuals while also creating space for frauds. Leibold cited one Chinese blogger's statement: “On the Internet, even [when] you provide facts about yourself, people won't believe it. They think that you make them up. So it doesn't matter whether you provide real or fake information because nobody trusts the information on the Internet." ${ }^{18}$ In the same article Leibold cited a survey showing that those who thought the Internet was reliable decreased from 52 percent to 26 percent between 2003 and 2007, while those who thought it was unreliable more than doubled, from 9 percent to 22 percent. ${ }^{19}$

The culture of distrust is reinforced by and reflected in the regressive digital culture described by Leibold. The new technologies that enable fast-paced, widely spread flows of messages excite but also quickly exhaust and disillusion users. The culture of suspicion, in turn, comes back to haunt online activism. In Han's (2012) observation, Chinese netizens have been extremely anxious about each other's identity and intentions in their online communication. While netizens could be successful in discrediting the Chinese Communist Party regime by exposing the state's manipulation and distortion of public opinions online, they are equally, if not more, suspicious of alternative views to the party-state. As the regime challengers practice pop activism and mock official lines, they are also ready to question the intentions and competence of democratic activists. Take the two bestknown leaders of the 1989 Tiananmen student movement, for example: according to Rongbin Han Chai Ling was accused of risking other students' lives for her personal ambition, and Wang Dan was accused of betraying China's national interests by receiving funds from the United States and Taiwan's proindependence DPP administration. Online platforms, therefore, could work to silence as much as to encourage public forums. ${ }^{20}$ Han notes that such suspicion and anxiety over others' identity and intentions has led online communities to isolate themselves with highly guarded entrances instead of retaining more inclusive networks in cyberspace.

As a result, there has been a strong public outcry for more, rather than less, state control of the Internet to maintain social stability. Nearly 84 percent of respondents to a survey thought that content on the Internet should be controlled, with 83 percent identifying violence, 65 percent malicious speculation, and nearly 30 percent online chatting as in need of control, and 85 percent looked to the government to censor this content. Between 2003 and 2007, there was an over 50 percent decline in those who thought that the Internet empowered the people. ${ }^{21}$

\section{THE POWER OF THE APOLITICAL: TZU CHI}

A more systematic comparison of social media in Taiwan and China is beyond the scope of this chapter. But one of the possible directions for further investigation 
is the paradoxical and multidimensional connections between public trust and politics. While Taiwanese netizens have organized alternative forums with great potential for political mobilization, they have tended to shy away from outright partisan politics. In the Chinese case, as Leibold has pointed out, one consequence of the loss of public trust in social media has been increasing popular demand for more, not less, state intervention in regulating cyberspace. ${ }^{22}$

In this final section, I will bring in another case of social entrepreneurialism from Taiwan to further illustrate the paradoxical relationship between public trust and politics and to show how an allegedly apolitical group has built the most powerful social organization in Taiwan, an organization that has now established itself in China as well.

Post-martial law Taiwan has seen a rapid expansion of religious and spiritual institutions. Quite a few Buddhist temples have expanded into large-scale and well-financed modern organizations. Buddhist organizations have contributed to the proliferation of welfare institutions, the internationalization of the revival movement, and increasing religious links between Taiwan and mainland China.

One of the best-known and largest Buddhist organizations active in Taiwan and internationally is a religious philanthropy group called Buddhist Compassion Relief Tzu Chi Foundation (hereafter Tzu Chi). Tzu Chi started as a small Buddhist charity of fifty-plus members in the impoverished coastal region of eastern Taiwan in 1966. By 2009 it boasted five million followers in Taiwan and overseas. Tzu Chi is also markedly matriarchal. The leader is a woman, a smallframed yet highly charismatic Buddhist Dharma nun called Master Cheng Yan. Tzu Chi's thirty founding members were all women, and in 2009 about 80 percent of the most active followers and volunteer charity workers were women, particularly middle-class, middle-aged women. ${ }^{23}$

While the matriarchal nature of Tzu Chi distinguishes it from other religious institutions in Taiwan, Tzu Chi has also demonstrated impressive managerial capability. In three decades, Tzu Chi Foundation grew from a small charity to a large international organization with 63 branch operations in Taiwan and another 372 branches in forty-seven countries, eight hundred full-time staff, and five million followers. It is included in the case study bank of Harvard Business School. In addition to its religious activities and organizations, Tzu Chi operates charity and disaster relief agencies, which now run three state-of-the art, nine-hundred-bed hospitals, a television channel, a publishing house, and a secular university that includes a well-respected medical school, several middle schools, and one of the most important bone marrow donation centers in Taiwan. In addition to large investment projects like hospitals, universities, and schools, Tzu Chi runs five thousand volunteer-based recycling centers with two hundred thousand volunteers all over Taiwan, turning millions of recycled PET bottles into clothing and disaster 
relief blankets. By 2010 the company that was in charge of the recycle-reuse project had annual revenue over US $\$ 3$ million.

An important feature of Tzu Chi is its principle of political neutrality. Master Cheng Yan has explicitly required Tzu Chi members to refrain from any kind of political activities. Unlike many celebrities in Taiwan, Master Cheng Yan herself has never openly supported any presidential candidates or politicians, and members of all ranks have to resign from Tzu Chi if they become involved in political campaigns, elections, or demonstrations. Master Cheng Yan's "ten precepts" include the five Buddhist ones of no killing, no stealing, no sex outside of marriage, no lying, and no drinking, as well as five more that she has added to the list: no smoking or using narcotics; no betel nuts; no gambling, no violation of traffic laws, and no participation in political activities or demonstrations. Tzu Chi's environmentalism, for instance, remained tied to recycling, for which the government also campaigns. Tzu Chi would not, however, protest against nuclear power plants or any specific polluting factories. In the name of universal love and harmony, and upholding the principle of not taking political sides, Tzu Chi systematically avoided any kind of confrontation.

This very explicit principle of political neutrality was not necessarily a "traditional" Buddhist value, however. Politically charged action has been characteristic of a long history of popularizing Buddhist movements in China. These sects often attempted to move Buddhism out of the monastery and into the streets, away from sophisticated philosophy and toward actions that anyone could perform, with a vision of this-worldly, collective salvation.

The case for the Buddhist tradition of political involvement is made even stronger if we look at Buddhist organizations and activities in other parts of Asia, including those in Thailand, Japan, Vietnam, Myanmar, Sri Lanka, and Tibet. In these societies we find that monks (mostly monks, not nuns) have not shunned either modest or aggressive political involvement and have engaged in protests against and resistance to secular states or have advocated alternative sources of authority. In contrast, Buddhist organizations in Taiwan general, and Tzu Chi in particular, have embraced no radical theology and have always adhered to the principle of political neutrality. Buddhist organizations were not part of the democracy movement in Taiwan in the 1980s, and they remained politically neutral after the lifting of martial law in $1987 . .^{24}$

Tzu Chi's political neutrality has been a form of moral capital in post-martial law Taiwan. As André Laliberté has suggested, the politics of post-martial law Taiwan was highly divided. The division was first drawn between those who were born in mainland China (mostly military and government personnel and those who moved to Taiwan in 1949 when the Nationalists were defeated by the communists), and those who identify themselves as genuine Taiwanese (whose ancestors, most of them peasants, had migrated to Taiwan from southern China three hundred 
years earlier). This line between "insiders" and "outsiders" was further reinforced by their presumed political stance over the issue of Taiwan-China relations. While "outsiders" were generally thought to be supportive of unification with mainland China, "insiders" were thought to lean toward Taiwan independence. Politicians of the DPP when it was an opposition party exploited this division to consolidate opposition energies and defeat the KMT, which had been dominating Taiwanese mainstream politics for half a century, in the 2000 presidential election. But this identity politics in Taiwan has not led to the type of violent conflicts found in many other parts of the world and history.

This is where the "apolitical" Tzu Chi and other Buddhist institutions come in. In a strongly politicized society with an active market of ideologies, and under increasing competition for resources with other religious and secular nongovernmental and nonprofit organizations, Tzu Chi found itself a niche featuring no political ideologies or claims. Positioned above and beyond secular politics, which was thought to be corrupted by money and power, Tzu Chi has attracted members from all ideological camps who were looking for a Pure Land in the mind. The more apolitical Tzu Chi insisted on being, the more its political influence over the state bureaucracy and politicians across different camps has increased. In a place where most people are sick and tired of politics and excessive commercialization, Tzu Chi and Master Cheng Yan stand on a moral plateau that few politician or CEOs can reach. In anthropologist Julia Huang's account, the secretariat office of the premier of the Executive Yuan told her that Tzu Chi's representative had enjoyed special treatment by the government. ${ }^{25}$ Tzu Chi representatives did not have to make an appointment with the minister's secretariat in advance before they met. Often the former just called from a mobile phone while they were only minutes away from the Executive Yuan. And these representatives reiterated that they were "doing good things" when they negotiated with the minister's secretariat for the government's support. Even high-ranking government officials feel they cannot afford to offend Tzu Chi. Unlike other religious leaders in Taiwan, Master Zheng Yan has never made a public appearance in presidential election campaigns for any candidate. But President Ma Ying-jeou of the KMT attended one of Tzu Chi's recycling centers and worked as a volunteer sorting out plastic bottles for a couple of hours.

Tzu Chi, on account of its political neutrality, has also turned out to be very useful to the Taiwanese government in its attempts to expand its much-contracted position in international diplomacy. As the result of China's diplomatic campaign against Taiwan, Taiwan is recognized as an independent sovereignty by only twenty-three countries, many of which are island countries of the South Pacific. Tzu Chi has become one of the most important venues for the Taiwanese government to promote its "People to People" diplomacy, represented by the establishment of the Committee of Nongovernmental Organizations under Taiwan's Ministry of 
Foreign Affairs. And given the political sensitivity of the issue of unification and independence, Tzu Chi, by declaring its political neutrality in humanitarian works, much like other international aid agencies, has paved the way for Taiwan's religious and social groups to cross the Taiwan Strait and expand their operations and networks in China. As mentioned earlier, Tzu Chi's relief workers have been able to enter mainland China despite the PRC's reputation for being highly cautious of accepting foreign aid and relief workers. During the Sichuan earthquake in China of 2008, Tzu Chi was the first non-PRC aid team approved by the PRC government to enter the quake zone. In 2010, after twenty years of working in various Chinese provinces, Tzu Chi became the first and the only international nonprofit organization to be approved by the State Department to establish a nationwide operation in China.

This chapter has explored Taiwan's changing state-societal relationship in the era of the postdevelopmental state, as well as the interplay of information technology, oppositional politics, and social activism. What I found most intriguing in this triangular dynamic is the paradox that in multiparty-democratic Taiwan, social mobilizers have claimed an apolitical stance in order to earn public trust, whereas in single-party-dominant China social media participants have turned to the state for restoration of public trust. The apolitical yet powerful charity organization of Tzu Chi further illuminates the power of the apolitical by pushing the limits of Taiwan's otherwise much-constrained diplomatic relationship internationally and with China. Changing state-society relationships in Taiwan and China are inevitably affected by the changing Taiwan-China relationship, and the reverse is also true.

\section{NOTES}

1. I ended this research in 2012, before the Sunflower Movement took place in 2014. Since I have not yet conducted enough research regarding the political and social implications of that movement and related events, I did not include them in this chapter.

2. Statistics regarding investment in Taiwan's Science Parks and the microelectronics industry in the last few years can be found in Hsinchu Science Park Bureau, Ministry of Science and Technology, Taiwan, ROC, "Hsinchu Science Park 2009 Annual Report," 2009, www.sipa.gov.tw/file/20100819093820.pdf.

3. An increasing number of firms, including Acer and Foxconn, among many others, are located right outside Hsinchu Science Park to avoid excessive government intervention, while taking advantage of the industrial cluster in the area.

4. In April 2011, as the result of persistent and well-networked campaigns by farmers, students, intellectuals, and environmentalist groups, the government was forced to halt a plan for a major petrochemical complex to be built on a wetland area in Zhanghua, southern Taiwan.

5. Leh-chyun Lin, keynote speech at the annual meeting of the International Press Institute, Taipei, September 2011.

6. Zhuang Feng-jia, "Impact of Citizen Journalism on Public Policies in Taiwan" (MA thesis, National Taiwan University, 2011), 24. 
7. Philip Harding, "PeoPo Helps Taiwanese Public Broadcaster to Restore Trust," Guardian, February 15, 2010, www.guardian.co.uk/media/2010/feb/15/citizen-journalism-taiwan.

8. Zhuang Feng-jia, "Impact of Citizen Journalism," 25.

9. Lin, keynote speech.

10. Ibid.

11. Zhuang Feng-jia, "Impact of Citizen Journalism," 71.

12. Ibid.

13. Lin, keynote speech.

14. James Leibold, "Blogging Alone: China, the Internet, and the Democratic Illusion?, Journal of Asian Studies 70, no. 4 (2011): 1023-41; Rongbin Han, "Challenging the Regime, Defending the Regime: Contesting Cyberspace in China" (PhD diss., University of California, Berkeley, 2012).

15. Leibold, "Blogging Alone," 9.

16. Lisa Chiu, “Outbreak of Rumors Has China Reeling," SFGate.com, May 7, 2003, http://articles. sfgate.com/2003-05-07/news/17493093_1_sars-cases-beijing-mayor-meng-xuenong-sars-epidemic.

17. Wu Zhong "'Paper Tiger' Tales Shred Credibility," Asia Times, April 3, 2008, www.atimes.com/ atimes/China/JDo3Ado1.html.

18. Liu Xun, "Online Posting Anxiety: Impacts of Blogging," Chinese Journal of Communication 3 , no. 22 (2010): 202-22, cited in Leibold, "Blogging Alone."

19. Guo Liang, Surveying Internet Usage and Its Impact in Seven Chinese Cities (Shanghai: Center for Social Development, Chinese Academy of Social Sciences, 2007), 9-11, cited in Leibold, "Blogging Alone," 10.

20. Han, "Challenging the Regime."

21. Liang, Surveying Internet Usage, 86, cited in Leibold, "Blogging Alone," 11.

22. Leibold, "Blogging Alone." For details, see You-tien Hsing, "Development as Culture: Human Development and Information Development in China," in Reconceptualizing Development in the Global Information Age, ed. Manuel Castells and Pekka Himanen (Oxford: Oxford University Press, 2014), $116-39$.

23. However, it has never organized as a women-only organization. In fact, in the last few years it has been getting an increasing number of male members and leaders at different levels.

24. André Laliberté, "'Buddhism for the Human Realm' and Taiwanese Democracy," in Religious Organizations and Democracy in Contemporary Asia, ed. Tung-ren Cheng and Deborah Brown (Armonk, NY: M.E. Sharpe, 2005), 55-82.

25. Julia Huang, Charisma and Compassion: Cheng Yen and the Buddhist Tzu Chi Movement (Cambridge, MA: Harvard University Press, 2009). 
